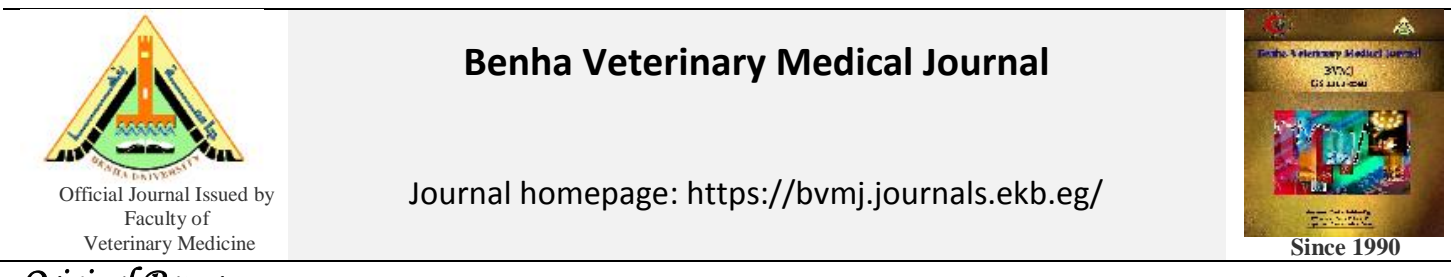

Original Paper

\title{
Effect of dietary nucleotide supplementation on broiler performance and economic efficiency
}

Nasser E. Khedr, Tahia E. Ahmed, Reda Hamed

Department of Nutrition and Clinical Nutrition, Faculty of Veterinary Medicine, Benha University. Egypt.

\section{ARTICLE INFO}

Keywords

Broiler chicks

Chick performance

Economic efficiency.

Nucleotide feeding

Received 28/07/2020

Accepted 10/08/2020

Available On-Line

$01 / 10 / 2020$

\begin{abstract}
The present experiment was designed to investigate the effect of nucleotide as an immunostimulant for broiler chicks in terms of chick performance and economic efficiency. A total number of two hundred forty-one-day-old broiler chicks (Ross 308) were randomly distributed into four different treatment groups (A, B, C and D), of three replicates (20 chicks / replicate). The chicks in control group (A) were fed negative control diet, group B were fed diet containing (Nucleoforce $\left.{ }^{\circledR}\right)(0.025 \%$ ) in first 10 days of age, group B were fed diet containing (Nucleoforce $\left.{ }^{\circledR}\right)(0.025 \%)$ in first 25 days of age. While group D was fed diet containing Nucleoforce ${ }^{\circledR}(0.025 \%)$ from zero day till slaughtering. Results showed that, groups fed diet supplemented with Nucleoforce ${ }^{\circledR}$ recorded improvements in live body weight, body weight gain and relative growth rate with no significant difference in feed intake and feed conversion index than the control group. Economic efficiency showed non-significan difference between control group and other groups but group (D) recorded high value 0.94 more than control group (A) 0.84 . It was concluded that, inclusion of nucleotide $0.025 \%$ in broiler diets had a positive role in improvement of final body weight, body weight gain, feed conversion ratio and economic efficiency.
\end{abstract}

\section{INTRODUCTION}

Antibiotics were used in diet at sub-therapeutic levels years ago to enhance the efficiency of poultry (Chattopadhyay, 2014). But it has produced residues in animals and humans in feed and cause a bacterial resistance so, medical warnings thus induced the complete antibiotics removal from feed stuffs (Ronquillo and Hernandez, 2017). As a result of recent policy limitation and reduction of the antibiotic use in animal feed in the European Union and the United States, there has been a fundamental increase in benefits in the use of alternative materials (including nucleotides) to provide benefits to animal safety and growth performance (Shurson, 2017). Nucleotides are biological molecules necessary for most biological processes within the body; their sources include dietary intakes, recovery from salvage pathway and de novo synthesis; although, under normal conditions, endogenous source is thought to meet the needs of healthy individuals sufficiently. While, there is some condition characterized by increased demand for nucleotides, such as intestinal injury, rapid development, immunosuppression or reduced protein intake, dietary sources are also essential. (Hess and Greenberg, 2012).

Nucleotide supplementation lead to increase body weight gain and FCR, but not affect feed intake (Salah et al., 2019). Also, nucleotide lead to increase intestinal villi correspond to increase surface area of the intestine and higher activities of digestive enzymes, therefore, increased nutrient absorption and improved digestibility (Gao et al.,
2008). Adding nucleotide in feed may be useful for improving economic efficiency in broilers (Daneshmand et al., 2017). Also, addition of nucleotides in broiler starter diets can provide a tool to increase profitability for broiler producers (Kocher et al., 2010).

The present experiment aimed to investigate the effect of nucleotide as an immunostimulant for broiler chicks in terms of chick performance and economic efficiency

\section{MATERIAL AND METHODS}

\subsection{Birds, housing and management}

The present study was carried out by using 240 one-day old chick (Ross 308) broiler chicks. The chicks reared at suitable environment. The chicks were randomly allocated into 4 groups, each group contain 3 replicates of 20 chicks each kept on a deep litter system. All groups were maintained under good ventilation and intermittent lightening program (23 hours $: 1$ hour) (lighting: darkness). Feed and water were offered ad-libitum. All birds were systematically vaccinated against Newcastle, IB and Gumburo and other needed prophylactic measures.

\subsection{Diets}

The chicks were distributed into 4 treatment groups (A, B, $\mathrm{C}$ and $\mathrm{D}$ ). A considered as negative control group and fed basal diet, group B were fed diet containing (Nucleoforce $\left.^{\circledR}\right)(0.025 \%)$ in first 10 days of age, group B were fed diet containing (Nucleoforce $\left.{ }^{\circledR}\right)(0.025 \%)$ in first 25 days of age. While group $\mathrm{D}$ were fed diets containing

\footnotetext{
* Corresponding author: Reda Hamed, Department of Nutrition and Clinical Nutrition, Faculty of Veterinary Medicine,
}

Benha University. Egypt. 
(Nucleoforce $\left.^{\circledR}\right)(0.025 \%)$ from zero day till slaughtering. Nutrient requirements with calculated analysis were determined according National Research Council NRC, (1994) as described in tables (1). The chemical composition of the Nucleoforce used in this study was as follows: crude protein $(20.34 \%)$, protein nitrogen $(3.25 \%)$, Non-protein nitrogen $(12.09 \%)$, Crude fiber $(0.1 \%)$, Ash (3.38\%).

Table 1 The ingredient composition of starter diet (0-10 day). Grower diet (11-25 day ) and finisher diet (26-35 day) of the experimental groups .

\begin{tabular}{|c|c|c|c|c|c|c|}
\hline \multirow[t]{2}{*}{ Ingredients } & \multicolumn{2}{|c|}{ Starter diet } & \multicolumn{2}{|c|}{ Grower diet } & \multicolumn{2}{|c|}{ Finisher diet } \\
\hline & $\begin{array}{l}\text { Negative control } \\
\text { (A) }\end{array}$ & $\begin{array}{l}\text { Diet containing } \\
\text { Nucleoforce } \\
\text { (B, C \&D) }\end{array}$ & $\begin{array}{l}\text { Negative } \\
\text { control } \\
\text { (A\&B) }\end{array}$ & $\begin{array}{l}\text { Diet containing } \\
\text { Nucleoforce } \\
\text { (C\&D) }\end{array}$ & $\begin{array}{c}\text { Negative } \\
\text { control } \\
(\mathrm{A}, \mathrm{B} \& \mathrm{C})\end{array}$ & $\begin{array}{l}\text { Diet containing } \\
\text { Nucleoforce } \\
\text { (D) }\end{array}$ \\
\hline Yellow corn & 53.03 & 53.00 & 55.52 & 55.52 & 60.68 & 60.68 \\
\hline Soybean meal (46) \% & 35 & 35 & 33.7 & 33.7 & 27.5 & 27.5 \\
\hline Corn gluten meal \% & 4.7 & 4.7 & 3 & 3 & 3.5 & 3.5 \\
\hline Soybean oil \% & 2.4 & 2.4 & 3.4 & 3.4 & 4.3 & 4.3 \\
\hline Di calcium phosphate \% & 1.6 & 1.6 & 1.33 & 1.33 & 1.23 & 1.23 \\
\hline Limestone\% & 1.5 & 1.5 & 1.4 & 1.4 & 1.25 & 1.25 \\
\hline L-Lysine\% & 0.39 & 0.39 & 0.31 & 0.31 & 0.29 & 0.29 \\
\hline DL -Methionine\% & 0.33 & 0.33 & 0.3 & 0.3 & 0.26 & 0.26 \\
\hline Sodium chloride $\%$ & 0.33 & 0.33 & 0.31 & 0.31 & 0.31 & 0.31 \\
\hline Vit. \&Min. mixture \% & 0.3 & 0.3 & 0.3 & 0.3 & 0.3 & 0.3 \\
\hline Sodium bicarbonate $\%$ & 0.13 & 0.13 & 0.12 & 0.12 & 0.13 & 0.13 \\
\hline L -Threonine\% & 0.1 & 0.1 & 0.1 & 0.1 & 0.04 & 0.04 \\
\hline Ant-coccidia $\%$ & 0.05 & 0.05 & 0.05 & 0.05 & 0.05 & 0.05 \\
\hline Ant-clostridia \% & 0.03 & 0.03 & 0.03 & 0.03 & 0.03 & 0.03 \\
\hline Ant-mycotoxin \% & 0.05 & 0.05 & 0.05 & 0.05 & 0.05 & 0.05 \\
\hline Energy enzymes \% & 0.03 & 0.03 & 0.05 & 0.05 & 0.05 & 0.05 \\
\hline Nucleoforce \% & _- & 0.025 & - & 0.025 & - & 0.025 \\
\hline Emulsifier \% & 0.01 & 0.01 & 0.01 & 0.01 & 0.01 & 0.01 \\
\hline Phytase enzyme \% & 0.01 & 0.01 & 0.01 & 0.01 & 0.01 & 0.01 \\
\hline Protease enzyme \% & 0.01 & 0.01 & 0.01 & 0.01 & 0.01 & 0.01 \\
\hline Total & 100.00 & 100.00 & 100.00 & 100.00 & 100.00 & 100.00 \\
\hline \multicolumn{7}{|l|}{ Chemical composition } \\
\hline ME (Kcal/kg diet) & 3.051 .53 & 3.051 .53 & 3116.35 & 3116.35 & 3227.72 & 3227.72 \\
\hline $\mathrm{CP} \%$ & 23.02 & 23.02 & 21.50 & 21.50 & 19.51 & 19.51 \\
\hline $\mathrm{CF} \%$ & 3.26 & 3.26 & 2.20 & 2.20 & 2.20 & 2.20 \\
\hline Crude fat $\%$ & 5.03 & 5.03 & 6.04 & 6.04 & 7.03 & 7.03 \\
\hline Lysine \% & 1.35 & 1.35 & 1.25 & 1.25 & 1.09 & 1.09 \\
\hline Lysine dig \% & 1.25 & 1.25 & 1.13 & 1.13 & 0.98 & 0.98 \\
\hline Methionine $\%$ & 0.66 & 0.66 & 0.61 & 0.61 & 0.55 & 0.55 \\
\hline Methionine dig $\%$ & 0.62 & 0.62 & 0.58 & 0.58 & 0.58 & 0.58 \\
\hline Methionine + cysteine & 1.02 & 1.02 & 0.95 & 0.95 & 0.86 & 0.86 \\
\hline Methionine + cysteine dig $\%$ & 0.92 & 0.92 & 0.85 & 0.85 & 0.78 & 0.78 \\
\hline Threonine $\%$ & 0.91 & 0.91 & 0.86 & 0.86 & 0.74 & 0.74 \\
\hline Threonine dig $\%$ & 0.78 & 0.78 & 0.74 & 0.74 & 0.64 & 0.64 \\
\hline Calcium $\%$ & 1.05 & 1.05 & 0.95 & 0.95 & 0.85 & 0.85 \\
\hline Available phosphorus \% & 0.50 & 0.50 & 0.45 & 0.45 & 0.42 & 0.42 \\
\hline Sodium \% & 0.18 & 0.18 & 0.17 & 0.17 & 0.17 & 0.17 \\
\hline Chloride \% & 0.23 & 0.23 & 0.22 & 0.22 & 0.22 & 0.22 \\
\hline Potassium \% & 0.88 & 0.88 & 0.82 & 0.82 & 0.79 & 0.79 \\
\hline
\end{tabular}

\subsection{Experimental procedure}

Chicks had free choice access of feed and water and were systemically vaccinated against ND, IB and Gambaro according to the sanitary programs (Table 2) (Younes, 2016). Feed consumption was weekly estimated for each treatment. Live body weight was measured in grams for all birds at the start of the experiment and weekly.

Table 2 Vaccination program of broiler chicks.

\begin{tabular}{clll}
\hline Age (in days) & Name of vaccine & Type of vaccine & Route of vaccination \\
\hline 7 & Hitcher IB & $\begin{array}{l}\text { Living vaccine } \\
\text { Living vaccine } \\
\text { (mild strain) }\end{array}$ & Via eye drops \\
15 & Gambaro & $\begin{array}{l}\text { Living vaccine } \\
\text { Living vaccine } \\
\text { (mild strain) }\end{array}$ & Via eye drops \\
18 & Colon IB & Via drinking water \\
\hline
\end{tabular}

\subsection{Economic efficiency}

Economic efficiency measures calculated as the following:

- Total cost per chick $=$ Total feed cost (total variable cost + total fixed cost.

- Total variable cost $=$ total feed cost + chick price + cost of drug, vaccine and disinfection +litter price +rent.

- Total fixed cost $=$ building cost +equipment cost

- Total return per chick $(\mathrm{L} . \mathrm{E})=($ final body weight $(\mathrm{kg})$ $\mathrm{X}$ selling price of $\mathrm{kg}$ chick live body weight offered in the market (L.E)) + price of sailed litter.

- Net return per chick (L.E) $=$ Total return per chick total cost per chick (L.E). 
- Economic efficiency $=$ net return per chick/total cost per chick (L.E.).

- Relative economic efficiency = Economic efficiency of each experiment group/ economic efficiency of the control group X 100.

\subsection{Statistical analysis}

Data obtained from the experiment were analyzed by SPSS, Use one-way ANOVA analysis. Results for each group are expressed as Mean \pm SEM. Differences between means were tested for significance by using Duncan's Range test (Duncan, SPSS Student Version 10.0.7, 2000). Differences at the level of $(\mathrm{P}<0.05)$ were considered statistically significant.

\section{RESULTS AND DISCUSSION}

Regarding final body weight and weight gain data presented in table 3 and figure 1 and 2 revealed that, the feeding of Nucleoforce was justified, because groups fed diets containing Nucleoforce from zero day till slaughtering age showed an improvement in performance (1912.43 g BWG)when compared with control one (1739.40 g BWG) and other treated groups while group (B) was the least one among treated groups $(1835.21 \mathrm{~g}$ BWG).

Table 3 Effects of (Nucleoforce ${ }^{\circledR}$ ) on growth performance of broiler chicks (means $\pm \mathrm{SE}$ )

\begin{tabular}{|c|c|c|c|c|}
\hline \multirow{2}{*}{ Items } & \multicolumn{4}{|c|}{ Groups } \\
\hline & A & B & $\mathrm{C}$ & $\mathrm{D}$ \\
\hline Initial weight (gm) & $47.08^{b} \pm 0.30$ & $46.25^{\mathrm{b}} \pm 0.25$ & $47.63^{b} \pm 0.63$ & $49.17^{\mathrm{a}} \pm 0.44$ \\
\hline Final weight (gm) & $1786.49^{b} \pm 33.05$ & $1894.44^{\mathrm{a}} \pm 32.55$ & $1882.84^{\mathrm{a}} \pm 7.29$ & $1961.60^{\mathrm{a}} \pm 34.07$ \\
\hline Body weight gain(gm) & $1739.40^{b} \pm 33.31$ & $1848.19^{\mathrm{a}} \pm 32.74$ & $1835.21^{\mathrm{a}} \pm 7.03$ & $1912.43^{\mathrm{a}} \pm 34.02$ \\
\hline Daily body weight gain(gm) & $49.70^{b} \pm 0.95$ & $52.81^{\mathrm{a}} \pm 0.94$ & $52.43^{\mathrm{a}} \pm 0.20$ & $54.64^{\mathrm{a}} \pm 0.97$ \\
\hline Relative growth rate & $184.97^{b} \pm 0.34$ & $186.02^{\mathrm{a}} \pm 0.29$ & $185.55^{\mathrm{ab}} \pm 0.17$ & $185.67^{\mathrm{ab}} \pm 0.25$ \\
\hline Feed intake (gm) & $2801.79^{\mathrm{a}} \pm 85.62$ & $2973.88^{\mathrm{a}} \pm 33.85$ & $3017.76^{\mathrm{a}} \pm 59.86$ & $3042.08^{a} \pm 97.64$ \\
\hline Daily feed intake(gm) & $80.05^{\mathrm{a}} \pm 2.45$ & $84.97^{\mathrm{a}} \pm 0.97$ & $86.22^{\mathrm{a}} \pm 1.71$ & $86.92^{\mathrm{a}} \pm 2.79$ \\
\hline Feed conversion efficiency & $1.61^{\mathrm{a}} \pm 0.02$ & $1.61^{\mathrm{a}} \pm 0.05$ & $1.64^{\mathrm{a}} \pm 0.03$ & $1.59^{\mathrm{a}} \pm 0.07$ \\
\hline Survival rate $\%$ & 98.30 & 100.00 & 98.30 & 98.30 \\
\hline European broiler index & $303.47^{\mathrm{a}} \pm 5.74$ & $328.72^{a} \pm 15.38$ & $313.59^{\mathrm{a}} \pm 0.83$ & $338.44^{\mathrm{a}} \pm 14.69$ \\
\hline \multicolumn{5}{|c|}{ Values are means \pm standard errors. Means with different letters at the same raw differ significantly at ( $(\mathrm{P} \unlhd .05$ ). } \\
\hline \multirow[t]{2}{*}{ Items } & \multicolumn{4}{|c|}{ Groups } \\
\hline & A & B & $\mathrm{C}$ & $\mathrm{D}$ \\
\hline Number of chicks & 60 & 60 & 60 & 60 \\
\hline Price per chick (L.E) & 4.25 & 4.25 & 4.25 & 4.25 \\
\hline Final body weight (gm) & $1786.49^{b} \pm 33.05$ & $1894.44^{\mathrm{a}} \pm 32.55$ & $1882.84^{\mathrm{a}} \pm 7.29$ & $1961.60^{\mathrm{a}} \pm 34.07$ \\
\hline Average daily feed intake (gm) & $80.05^{\mathrm{a}} \pm 2.45$ & $84.97^{\mathrm{a}} \pm 0.97$ & $86.22^{\mathrm{a}} \pm 1.71$ & $86.92^{\mathrm{a}} \pm 2.79$ \\
\hline Vaccination (L.E) & 0.63 & 0.63 & 0.63 & 0.63 \\
\hline Drugs (L.E) & 1.50 & 1.00 & 1.00 & 1.00 \\
\hline Disinfection & 0.29 & 0.29 & 0.29 & 0.29 \\
\hline Litter & 1.45 & 1.45 & 1.45 & 1.45 \\
\hline Electricity & 0.33 & 0.33 & 0.33 & 0.33 \\
\hline Feeder \&Waterer & 0.094 & 0.094 & 0.094 & 0.094 \\
\hline Rent & 1 & 1 & 1 & 1 \\
\hline Total feed cost (L.E) /chick & $14.18^{\mathrm{b}} \pm 0.43$ & $16.72^{\mathrm{a}} \pm 0.19$ & $16.97^{\mathrm{a}} \pm 0.34$ & $17.10^{\mathrm{a}} \pm 0.55$ \\
\hline Total cost (L.E) & $23.87^{\mathrm{a}} \pm 1.19$ & $24.05^{\mathrm{a}} \pm 0.31$ & $24.19^{\mathrm{a}} \pm 0.27$ & $24.37^{\mathrm{a}} \pm 0.31$ \\
\hline Selling price (L.E) & 24 & 24 & 24 & 24 \\
\hline Return from litter & 0.83 & 0.83 & 0.83 & 0.83 \\
\hline Total return/chick & $43.71^{\mathrm{b}} \pm 0.79 \pm$ & $46.27^{\mathrm{a}} \pm 0.78 \pm$ & $46.02^{\mathrm{a}} \pm 0.18 \pm$ & $47.91^{a} \pm 0.81 \pm$ \\
\hline Net revenue/chick & $19.84^{\mathrm{b}} \pm 0.81$ & $22.25^{\mathrm{ab}} \pm 1.06$ & $21.82^{\mathrm{ab}} \pm 0.17$ & $23.54^{\mathrm{a}} \pm 1.02$ \\
\hline Economic efficiency & $0.84^{\mathrm{a}} \pm 0.07$ & $0.93^{\mathrm{a}} \pm 0.06$ & $0.90^{\mathrm{a}} \pm 0.02$ & $0.94^{\mathrm{a}} \pm 0.05$ \\
\hline relative Economic efficiency\% & $100.00^{\mathrm{b}} \pm 0.00$ & $115.81^{\mathrm{ab}} \pm 7.04$ & $112.79^{\mathrm{ab}} \pm 2.01$ & $120.92^{\mathrm{a}} \pm 6.52$ \\
\hline
\end{tabular}

Live body weight $(\mathrm{g})$

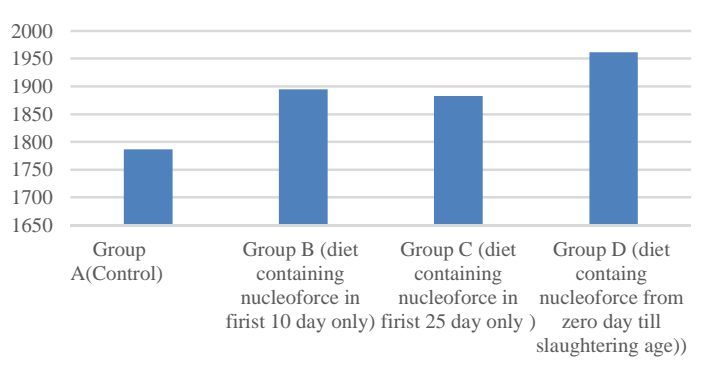

Fig. 1 Effect of nucleotides on live body weight.

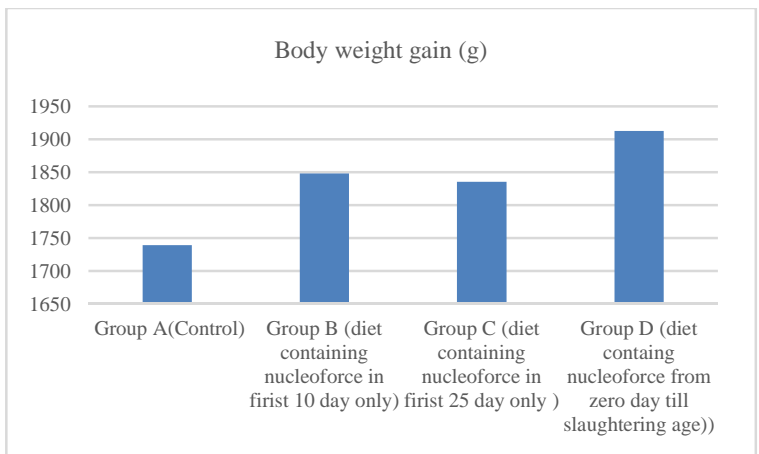

Fig. 2 Effect of nucleotides on body weight gain. 
This result agreed with Kocher et al. (2010) who recorded that nucleotide supplementation is very important in industry of broiler by growing broiler much faster as it enabled broiler chick to rich marketing weight at earlier age and this occurred as a result of early and rapid development of intestinal tract and mature villi. Other one explained cause of increasing body gain, Pelícia et al. (2010) who explained the cause of improvement of growth performance and said that nucleotides aimed to increase villi length which in term lead to increasing surface area of absorption which result in increasing digestion and absorption of nutrient. Another explanation of increasing body weight by Grimble and Westwood (2000) who suggested that deficiency of nucleotides in diet may impair intestine, immune, liver and heart functions as endogenous source of nucleotide from them are inadequate. The slowly endogenous source from the bird in combination with increased demand result in the requirements for additional nucleotides added directly to the poultry feed. Therefore, dietary supplementation of nucleotides helps in the growth of rapidly dividing cells without the expense of more energy and thereby increase the productivity in birds. Also, result agreed with Jung and Betal (2012) who reported that provision of nucleotide in diet was necessary to maintain maximum growth performance when birds are reared under environmental stress conditions. In addition, Salah et al. (2019) who reported that dietary nucleotide supplementation resulted in improvement in body weight gain and FCR, but not affected the feed intake. While result partially disagreed with. Gao et al. (2008) who reported that dietary supplementation with nucleotides at $2.5 \mathrm{~g} / \mathrm{kg}$ increased growth performance, but its effect at greater inclusion levels $(5.0$ or $7.5 \mathrm{~g} / \mathrm{kg})$ was not significant.

During the period from (0- 5 weeks), As shown in table (3) fig (3) the statistical analysis showed that there were a significant $(p \circlearrowleft 0.05)$ increase in relative growth rate in group B (186.02) followed by group D (185.67) \&C (185.55), respectively.

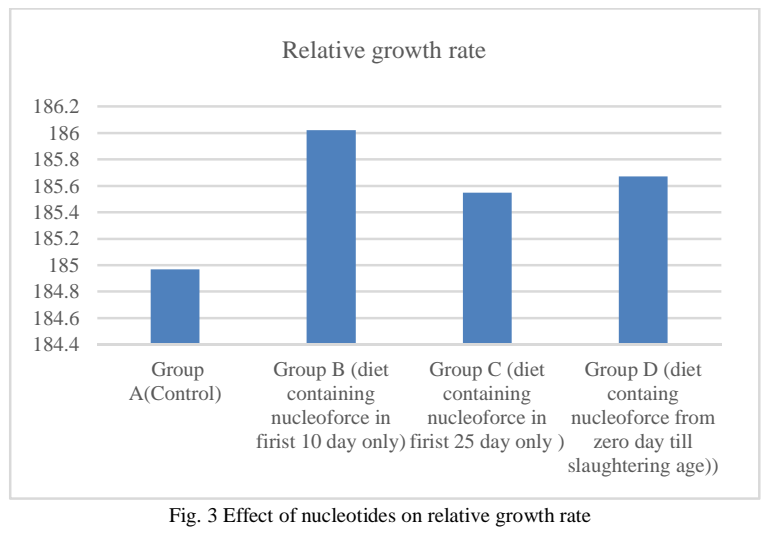

This finding agreed with Abd El-Wahab et al. (2019) who noted that dietary nucleotide supplementation had an important role in improving growth rate. In addition, Onifade et al. (1999) who found that the supplementation of nucleotides to poultry diet have beneficial role in growth rate through increasing live weight gain. Also, with Jung and Betal (2012) who noted that dietary nucleotide supplementation necessary to maintain maximum growth performance when birds are exposed to environmental stress conditions .While, this finding not supported by Cameron et al. (2001) who found no difference in growth rate between nucleotide supplemented when compared with un supplemented diets.

In the period from (0- 5 weeks), the statistical analysis indicated that there was no significant difference between all groups in total feed intake as shown in fig (4).

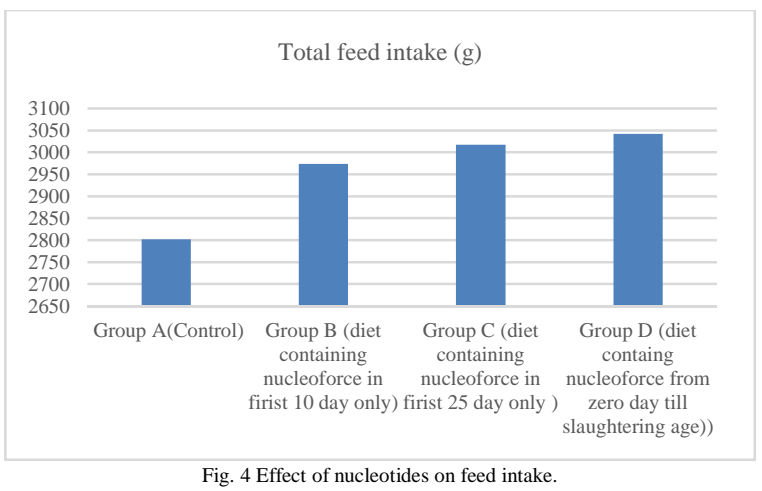

This may be attributed to the balanced diet offered to all groups. These results agreed with those obtained by Salah et al. (2019) who mentioned that nucleotide supplementation had no significant importance on the feed intake between different groups. Also, Zauk et al. (2006) who reported that broiler chicks fed pre starter diets (1-7 days of age) containing graded levels $(0,1,2,3$ or $4 \%)$ of NuPro (nucleotides) result in No significant differences in feed intake. In addition, Deng et al. (2005) who found that the addition of 0.5 and $1.0 \%$ nucleotides did not impact on feed consumption of Leghorn-type chickens under normal conditions. while result not supported by Esteve-Garcia et al. (2007, August) who noted that there is a significant decrease in the feed intake of broilers supplemented with 0.5 percent nucleotide / $\mathrm{kg}$ of feed during the starter period. In addition, Shivkumar et al. (2009) mentioned that the effects of feeding NuPro (nucleotides) at different time interval i.e. for 7, 14 and 42 days in broiler chickens led to higher feed intake in 14 days treatment but at the end, lower feed consumption in birds fed NuPro for 7 and 14 days. A better weight gain and lower FCR was also reported in all the NuPro diets both on day 7 and 42 as compared to control (P $₫ .05$ ).

The effect of dietary supplementation of Nucleoforce on feed conversion ratio (FCR) showed in Table (3) and figures (5).

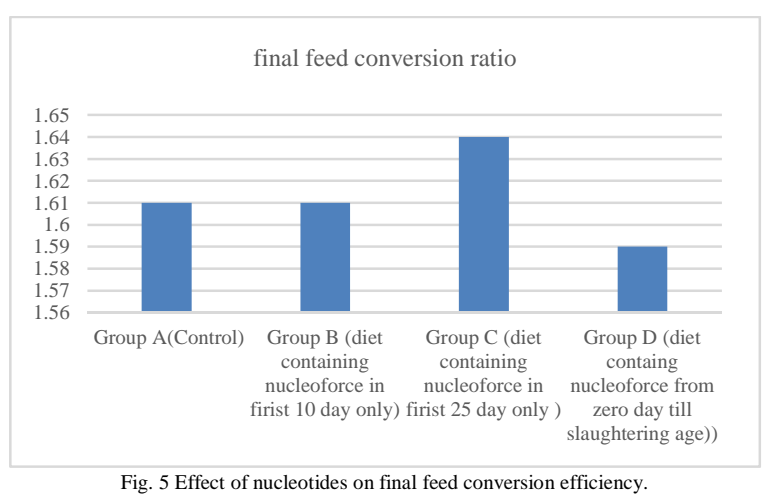

The obtained data clarify that there was non-significant difference in feed conversion ratio (FCR) between all dietary treatments and control group during experimental period. However, during all experimental period (0-5 
weeks) groups received diet containing Nucleoforce showed improvement more than others. This improvement may be attributed to the higher final body weight. These results supported by Owens and McCracken (2006) who found no significant difference in feed: gain value in panned birds over all experimental period. Also, Pelícia et al. (2010) who noted no differences in feed conversion ratio between nucleotide supplemented and negative control group. On the other hand, Masey O'Neill et al (2014) who verified that the addition of yeast extract of Saccharomyces cerevisiae, containing high nucleotides, to broiler pre starter diets led to beneficial effects on the feed conversion ratio of the birds.

Data presented in table 3 and figure 6 revealed that, there was no death in group B ,fed diet containing Nucleoforce in first 25 day only, (survival rate $100 \%$ ) this revealed the role of Nucleoforce in improvement of immunity to overcome disease.

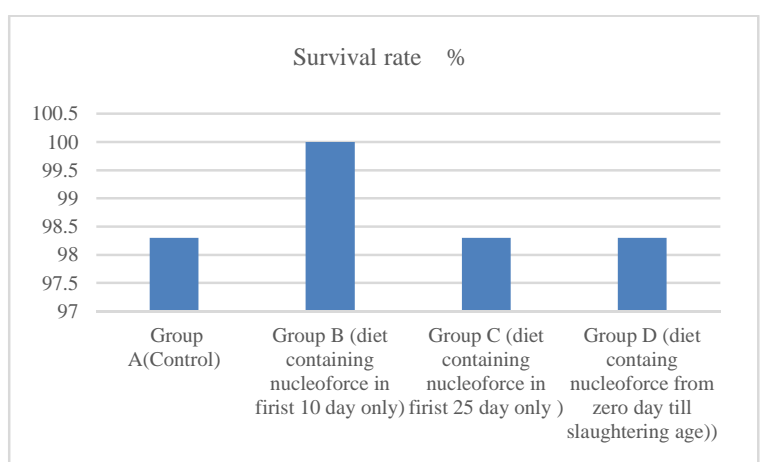

Fig. 6 Effect of nucleotides on survival rate

This result agreed with Rutz et al. (2008) who told that chicks fed diet containing nucleotides under stress condition mortality decreased by approximately $30 \%$. Also, Shivakumar et al. (2009) who recorded that birds fed Nupro (nucleotides) diets showed less mortality when compared with control birds. In addition, Daneshmand et al. (2017) who reported that mortality rate was less than $1 \%$ ( 2 from 360 chicks) in nucleotide fed broilers.

From table (4) and figure (8), (9) the cost of chicks, vaccine, disinfection, rent, litter, electricity and feeder, waterer was same in all group, but drugs cost increased in control group than nucleotides fed groups. total feed cost showed significant $(\mathrm{P}<0.05)$ increase in nucleotide fed groups (17.10), (16.97) and (16.72) L.E in group D, C and B respectively when compared with control one (14.18). Total cost was high in group (D) $(24.37$ L. E) that fed diet containing nucleotide from zero till slaughtering age, but control group was the least once. There was a significant $(\mathrm{P}$ $<0.05)$ increase in total return in group (D) $(47.91 \mathrm{~L} . \mathrm{E})$ compared with control one $(43.71$ L. E). net return showed a significant $(\mathrm{P}<0.05)$ increase in nucleotide fed groups it was high in group (D) $(23.54 \mathrm{~L} . E)$ than other treated groups and control one $(19.84 \quad L . E)$. There was no difference in economic efficiency between all groups but group (D) recorded high value 0.94 while in control group it reached 0.84 . there was a significant increase in group (D) reach $120.92 \%$ while in control group (A) it was 100 $\%$. These results supported by Ahiwe et al (2020) Who told that diet containing high nucleotides especially at 1.5 to $2.0 \mathrm{~g} / \mathrm{kg}$ diet result in improvement in broiler chicken performance (live body weight ,body weight gai and feed conversion ratio) and meat yield that led to increase in total return and economic efficiency Also, Fathi et al (2012) who reported that broilers fed diet containing high nucleotides result in increased $(\mathrm{P}<0.05)$ body weight when compared with control group. He added that, the highest inclusion level $(1.5 \mathrm{~g} / \mathrm{kg})$ recorded the highest weight higher percentage of major and minor breast muscles that result in improved economic efficiency. In addition, Wang et al. (2009) who stated that dietary nucleotide supplementation in broiler result in increasing live body weight, higher body weight gain and feed conversion ratio.

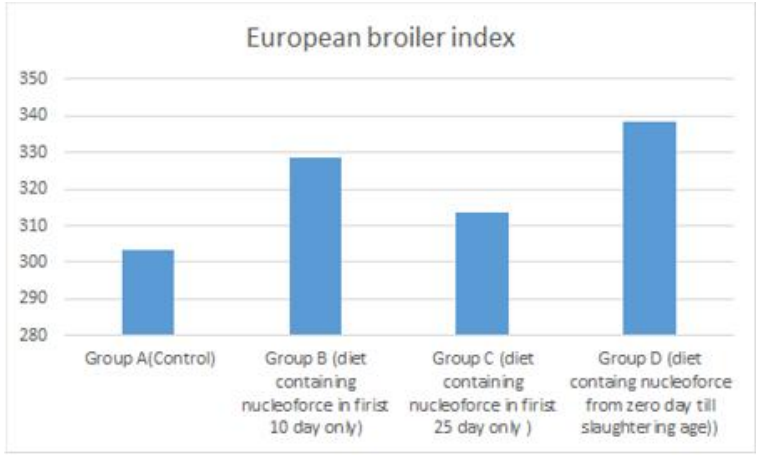

Fig. 7 Effect of nucleotides on European broiler index

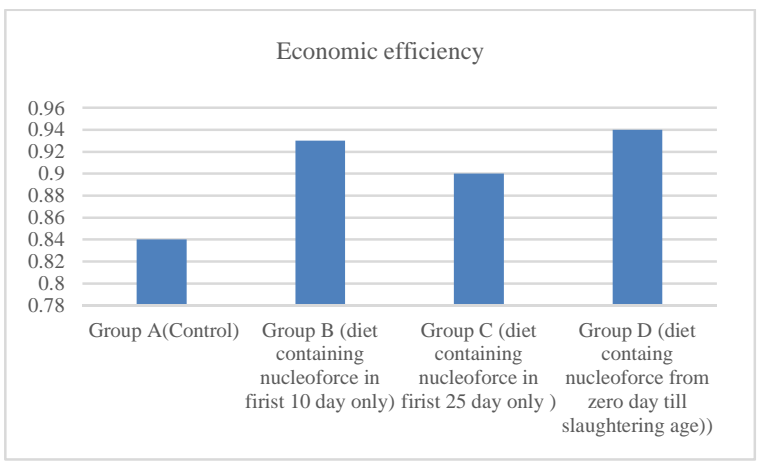

Fig. 8 The effect of nucleotide on economic efficiency of broiler chicks.

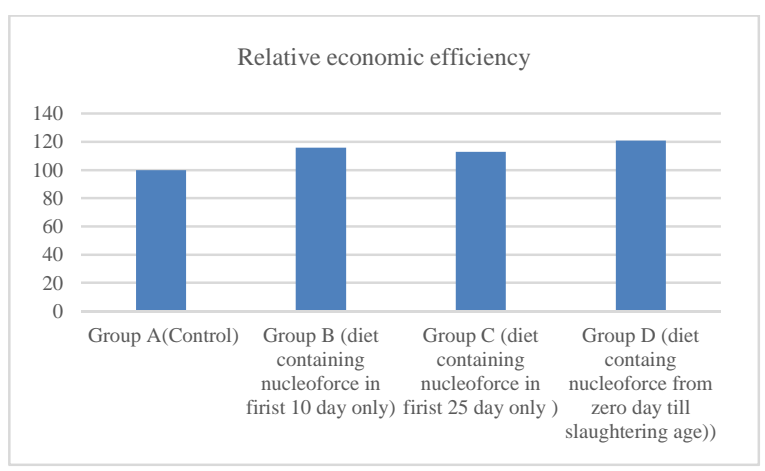

Fig 9 The effect of nucleotide on relative economic efficiency of broiler chicks.

\section{CONCULOSIONS}

From the obtained results, it was concluded that inclusion of nucleotide $0.025 \%$ in broiler diets from zero day till slaughtering age had a positive role in improvement final body weight, body weight gain, feed conversion ratio, total return and economic efficiency.

\section{CONFLICT OF INTEREST}

The authors declared no conflict of interest. 


\section{REFERENCES}

1. Abd El-Wahab, A. A., Mahmoud, R., Marghani, B. Gadallah, H. 2019. Effects of Yeast Addition to the Diet of Japanese Quails on Growth Performance, Selected Serum Parameters and Intestinal Morphology as well as Pathogens Reduction. Pakistan Veterinary Journal 40(2), 219-223.

2. Ahiwe, E. U., Abdallh, M. E., Chang'a, E. P., Omede, A. A., Al-Qahtani, M., Gausi, H., Hadden Graham, H., Iji, P. A (2020). Influence of dietary supplementation of autolyzed whole yeast and yeast cell wall products on broiler chickens. Asian-Australasian Journal of Animal Sciences, 33(4), 579-587.

3. Cameron, B. F., Wong, C. W., Hinch, G. N., Singh, D., Colditz, I. G. 2001. Effects of nucleotides on the immune function of early-weaned piglets. In Digestive Physiology of Pigs. Proceedings of the 8th Symposium. Wallingford: CABI Publishing pp. 66-68.

4. Chattopadhyay, M. K., 2014. Use of antibiotics as feed additives: a burning question. Frontiers in microbiology, 5 (334), 1-3

5. Daneshmand, A., Kermanshahi, H., Mesgaran, M. D., King, A. J., Ibrahim, S. A., Klasing, K. C. 2017. Combination of purine and pyrimidine nucleosides influences growth performance, gut morphology, digestive enzymes, serum biochemical indices and immune functions in broiler chickens. Animal feed science and technology, 228, 186193.

6. Deng, K., Wong, C. W., Nolan, J. V. 2005. Carry-over effects of dietary yeast RNA as a source of nucleotides on lymphoid organs and immune responses in Leghorn-type chickens. British poultry science, 46(6), 673-678.

7. Duncan, (SPSS program Version 10.0.7, June). (2000) ANOVA, (Analysis of variance), LSD (Least Significant Difference) and multiple range tests. Res., 28: 65-74. Biometrics, 11: 142

8. Esteve-Garcia, E., Martinez-Puig, D., Borda, E., Chetrit, C. 2007. Efficacy of a nucleotide preparation in broiler chickens. In Proceedings 16th European Symposium on Poultry Nutrition. Strasbourg, France pp. 511-514.

9. Fathi, M. M., Al-Mansour, S., Al-Homidan, A., Al-Khalaf, A., Al-Damegh, M. 2012. Effect of yeast culture supplementation on carcass yield and humoral immune response of broiler chicks. Veterinary World, 5(11), 651657.

10. Gao, J., Zhang, H. J., Yu, S. H., Wu, S. G., Yoon, I., Quigley, J., Gao, P.Y., Qi, G. H. 2008. Effects of yeast culture in broiler diets on performance and immunomodulatory functions. Poultry Science, 87(7), 13771384.

11. Grimble, G. K. and Westwood, O. M. R. 2000. Nucleotides In: German JB, Keen CL (Eds.), Nutrition and Immunology: Principles and Practice. Humana Press Inc., Totowa, NJ, USA, pp. 135- 144 .

12. Hess, J. R. and Greenberg, N. A. 2012. The role of nucleotides in the immune and gastrointestinal systems: potential clinical applications. Nutrition in Clinical Practice, 27(2), 281-294.
13. Jung, B. and Batal, A. B. 2012. Effect of dietary nucleotide supplementation on performance and development of the gastrointestinal tract of broilers. British Poultry Science, 53(1), 98-105.

14. Kocher, A., Naylor, A., Martin, C., Wilson, T., Hazeldene, J. 2010. Tools in early nutrition to maximize growth performance. In $21 \mathrm{st}$ annual Australian poultry science symposium pp. 60.

15. Masey-O'Neill, H. V., Singh, M., Cowieson, A. J. 2014. Effects of exogenous xylanase on performance, nutrient digestibility, volatile fatty acid production and digestive tract thermal profiles of broilers fed on wheat-or maizebased diet. British poultry science, 55(3), 351-359.

16. Onifade, A. A., Odunsi, A. A., Babatunde, G. M., Olorede B. R., Muma, E. 1999. Comparison of the supplemental effects of Saccharomyces cerevisiae and antibiotics in low protein and high fiber diets fed to broiler chickens. Archives of animal nutrition, 52(1), 29-39.

17. Owens, B. and McCracken, K.J. 2007. A comparison of the effects of different yeast products and antibiotic on broiler performance. Br Poult Sci. 48(1), 49-54

18. Pelícia, V. C., Sartori, J. R., Zavarize, K. C., Pezzato, A. C., Stradiotti, A. C., Araujo, P. C., Mituo, M.A.O., Madeira, L. A. 2010. Effect of nucleotides on broiler performance and carcass yield. Brazilian Journal of Poultry Science, 12(1), 31-34.

19. Ronquillo, M. G. and Hernandez, J. C. A. 2017. Antibiotic and synthetic growth promoters in animal diets: review of impact and analytical methods. Food Control, 72, 255-267.

20. Rutz, F., Xavier, E. G., Anciuti, M. A., Roll, V. F. B., Rossi, P. 2008. The role of nucleotides in improving broiler prestarter diets. Gut Efficiency: The Key Ingredient in Pig and Poultry Production, 155-165.

21. Salah, M., Suprijatna, E., Djauhari, M. L., Dwi, Y. V. 2019. The effects of nucleotide supplementation on the productivity, immune response and meat quality of broiler chicken reared under different environmental conditions. Livestock Research for Rural Development.31(11), 174.

22. Shivkumar, M.C., Narasimhamurthy, H.N., Swamy, H.V.L.N. 2009. Effect of feeding NuPro at different time intervals on the performance of commercial broilers. Abstracts of papers, Nutrition-I, symposia and oral session. International Poultry Scientific Forum. pp. 144

23. Shurson, G. C. 2017. The role of biofuels coproducts in feeding the world sustainably. Annual review of animal biosciences, 5, 229-254

24. Wang, Z., Cerrate, S., Coto, C., Sacakli, P., Yan, F., Costa, F. G. P., Waldroup, P. W. 2009. Evaluation of Nupro® yeast product in diets for broilers. International Journal of Poultry Science, 8, 515-520.

25. Younes, F. R. 2016. Response of Broiler chicks to Diet Containing Sunflower Meal, M. V. Sc., Faculty of Veterinary Medicine, Benha University.

26. Zauk, N. H. F., Lopes, D. C. M., Silva, L. M., Dallmann, P. R., Ribeiro, C. L. G., PINTO, J., Mielke, R.B., Anciuti, M.A., Rutz, F. (2006). Performance and carcass traits of broilers fed pre-starter diets containing Nupro®. Nutritional Biotechnology in The Feed and Food Industries, Posters presented at Alltech's 22nd Annual Symposium (Suppl. 1) Lexington, Ky, USA, p. 10 